\title{
Gillian Whitlock, Postcolonial Life Narratives:
}

\section{Testimonial Transactions}

\section{Kerry-Jane Wallart}

\section{OpenEdition}

1 Journals

Electronic version

URL: https://journals.openedition.org/ces/5669

DOI: $10.4000 /$ ces.5669

ISSN: 2534-6695

Publisher

SEPC (Société d'études des pays du Commonwealth)

\section{Printed version}

Date of publication: 1 April 2016

Number of pages: 141-142

ISSN: 2270-0633

\section{Electronic reference}

Kerry-Jane Wallart, "Gillian Whitlock, Postcolonial Life Narratives: Testimonial Transactions",

Commonwealth Essays and Studies [Online], 38.2 | 2016, Online since 06 April 2021, connection on 01

July 2021. URL: http://journals.openedition.org/ces/5669 ; DOI: https://doi.org/10.4000/ces.5669

This text was automatically generated on 1 July 2021.

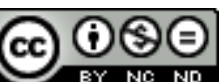

Commonwealth Essays and Studies is licensed under a Licence Creative Commons Attribution - Pas d'Utilisation Commerciale - Pas de Modification 4.0 International. 


\title{
Gillian Whitlock, Postcolonial Life Narratives: Testimonial Transactions
}

\author{
Kerry-Jane Wallart
}

\section{REFERENCES}

Gillian Whitlock. Postcolonial Life Narratives: Testimonial Transactions. Oxford: OUP, 2015. 242 p. ISBN (pb): 978-0-19-956062-2. £18.99

1 This recent delivery in the "Oxford Studies in Postcolonial Literatures" series edited by Elleke Boehmer constitutes an insightful delving into the narrative agencies of colonial and postcolonial texts at large. It does so by scrutinizing a limited but revelatory range of cases from the late $18^{\text {th }}$ century to nowadays; while it does not fully overlook the second $19^{\text {th }}$ century the present monograph recognizes the effects of the long $18^{\text {th }}$ century sentimentality in contemporary concerns about Human Rights, from postapartheid South Africa to Western countries facing repeated refugee crises, or to an Australia (possibly) coming to terms with the Stolen Generations. Whitlock problematizes the writing of selfhood and convincingly argues that while "autobiography" is not an appropriate concept for the (post)colonial context, constructing personhood and the expression of the "I" remains central. As a result, defining and circumscribing the notion of a "life narrative" extends far beyond the sort of generic categories and divisions that are, as Ashcroft et al. recall in The Empire Writes Back (1989), probably linked to Western practices only.

2 The volume falls into two parts, one colonial, the other postcolonial, upon the grounds that "there is an affinity between the production and reception of life narrative in colonial modernity and in the 'age of testimony' now" (16). Such a division never cancels or diminishes the author's immense skill in juxtaposing texts, be they theoretical, fictional or autobiographical, and weaving them together at the same time. Whitlock construes a trajectory and carefully recalls previous analyses while constantly resisting the temptation of systematic argumentation; the "transactions" in the 
subtitle, which heed the troubled relation between writer and reader in such matters, also illustrates metatheoretically, as it were, the progress she makes into her own research topic. Her method is admirable and enlightening throughout. Her scope is both acute and vertiginously wide, her detailed textual analyses being structured around an impressive theoretical apparatus.

Engaging in a revisiting of such figures as Equiano, Bennelong, Saartje Baartman, Mary Prince and Kah-ge-ga-gah-Bowh, the first part of the volume ("Colonial Testimonial, 1789-1852") exposes the difficulties and ambiguities surrounding the writ-ings of the "volatile" (76) colonized subject. The author travels easily between writers who are now considered part of the "Black Atlantic" (Equiano, Mary Prince) on the one hand, and on the other hand, Australia, South Africa and Canada. All five chapters retrace the links between the rise of an empathic era of sensibility, and an individualistic surge resulting in the prominence of the witnessing position. Drawing on Baucom among others, she presents a "melancholic witness" caught between coercion and relegation, between story-telling and (self-)censure.

4 A second and longer part ("The Passages of Testimony") scrutinizes the contemporary period and reconfigures the notion of testimony according to various contexts that are both contrasted and compared in the most appropriate way. The first chapter, centered around the South African Truth and Reconciliation Commission, connects novels and narratives by Jacob Dlamini, J. M. Coetzee, Antjie Krog and Nelson Mandela.

The author shows how texts might both originate from the specificities of a perspective and be ghosted by precedence and the communality of the experience of apartheid; she concludes that the "exhaustion of the western humanist language of recognition is played out" (101). In the following two chapters Whitlock goes on skilfully to unpack the echoes of the $18^{\text {th }}$-century "humanitarian revolution" and aptly uses the conclusions in Sarah Ahmed's The Cultural Politics of Emotion (2004) - among which one might quote her reflections on the "economy of affect" and her theorization of "fear." "Rape Warfare and Humanitarian Storytelling" tackles the silence often surrounding victims of rape in the Congo as well as the subjectivities and distortions which run galore around the figure of Dian Fossey, who died close-by, and whose testimony shows marks of gendered violence, semantically and otherwise. "Thresholds of Testimony" is a chapter about the "conscience industry" (Carter, qtd. 151) afflicting Australia around its national treatment of the Aborigines at the beginning of the $20^{\text {th }}$ century and centers around Sally Morgan's 1987 My Place. Whitlock sees that text as the locus for catharsis but also the reactivation of pre-existent codes of witness bearing.

6 The last chapter, concerned with "The Ends of Testimony," is a case-in-point of the volume's criss-crossing method, as it confronts three papers by Robert Young, Simon Gikandi and Peter Hulme about refugees, those "speechless emissaries" (178). Whitlock turns to Edwige Danticat's Brother, I'm Dying and the remediation of testimony that it represents, before addressing the question of the "Not-so-silent Hero" (189) with Dave Eggers' What is the What: The Autobiography of Valentino Achak Deng. By way of conclusion (a text pessimistically as well as overly humbly entitled "Salvage"), Whitlock "suggests an interlocking of pasts, presents, and futures across postcolonial life narrative" (201) and considers the texts gleaned throughout the volume as so many attempts at redeeming human experience against legal loss and literary silence.

7 Postcolonial Life Narratives makes a truly eye-opening read and will, I believe, prove useful much beyond the circle of scholars who are interested in questions of 
postcolonial autobiographies and testimonies, as it interrogates, in line with Spivak's "Can the Subaltern Speak," the way in which reception cannot be dissociated from issues of agency, legitimacy, self-fashioning and personal voice.

\section{AUTHORS}

\section{KERRY-JANE WALLART}

Kerry-Jane WALLART is a Senior Lecturer at Paris-Sorbonne. She has authored a number of chapters and articles on Caribbean literature, and more specifically on the works of Derek Walcott, Wilson Harris, Fred d'Aguiar, E. K. Brathwaite and Claude McKay. Her research extends geographically into Africa (Athol Fugard, Wole Soyinka, Ben Okri) and theoretically into generic reflections (the importance of performance in written texts, the proliferation of poetic forms in the novel, the reinvention of the short story form, the postcolonial reshuffling of generic distinctions in general). 